\title{
JOURNAL.RU
}

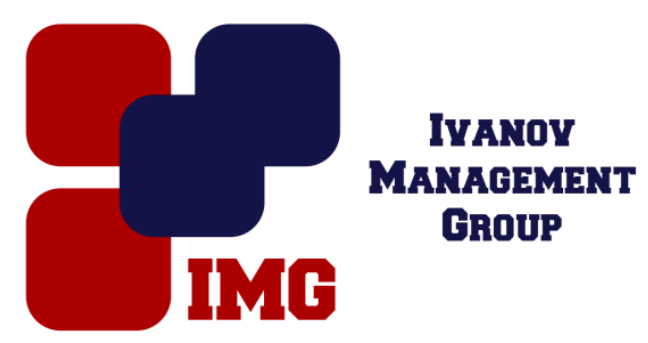

Галушко И. Г., Лопатюк Е.А., Кустова Д.М.

Кубанский государственный университет Краснодар, Россия

doi: 10.18411/lj-30-06-2017-43

idsp 000001:1j-30-06-2017-43

\section{Барьеры в педагогическом общении}

\section{Аннотация}

В общении формируется существенная концепция воспитательных отношений, содействующих производительности обучения и преподавания. В преподавательской деятельности общение обретает многофункциональный и весомый характер. Оно представляет собой механизм влияния, и простые требование и функции общения приобретают тут вспомогательную «нагрузку», таким образом, аспекты общечеловеческих нюансов переходят в элементы педагогической оригинальности.

Ключевые слова: общение, воспитание, педагогика, барьеры, фактор, взаимодействие, страх.

Исследования трудностей общения и практические исследования дают возможность использовать многочисленные приемы для межличностных отношений. В основном главными критериями межличностного общения считаются умения и навыки каждого для применения их в так называемых директивных приёмов реагирования при общении.Главными факторами неэффективности каждого настоящего общения является применение оборонительно-враждебной конфигурации или иными словами агрессивные действия.

В жизни человека, как в личной так и профессиональной имеются цели, которые должны включать в себя:

- достижения полного взаимопонимания с партнером; 
- психическое воздействие на партнёра для отстаивания своих интересов;

- собственной защите от нападок и агрессии;

Защитно-враждебное общение - это взаимодействие, направленное на психическое воздействие на собеседника в личных интересах, но проявляется в такой форме, чтобы унизить чувство собственного достоинства собеседника.

Установка в слаженности собственного поведения при общении с людьми значит проявление своей искренности в общении с ними. В практике слаженность действия обладает большой ролью в таком случае, когда мы проявляем на деле действительно те чувства, которые переживаем внутри в момент общения и тогда, когда мы сами осознаем своё эмоциональное состояние.Быть целиком слаженным в общении с абсолютно всеми людьми, все время и абсолютно во всех моментах разумеется невозможно, но слаженность поведения очень важна в тех ситуациях, когда собеседники хотят понять друг друга и хотят развивать свои взаимоотношения.

Одним из факторов появления психологического барьера могут быть социокультурные отличия между собеседниками в процессе общения. Различная интерпретация понятий, употребляемых в общении, может зависеть от сферы деятельности: политика, религия, общество. Так же в роли барьера может выступать само понимание партнёра в общении, как личности определенной деятельности, национальности, пола и возраста.

Психологические барьеры в общении появляются малозаметно и индивидуально, зачастую они никак не чувствуются лично самим человеком, однако немедленно замечаются со стороны окружающих. Человек перестает чувствовать неточность собственных действий, и убежден, то что контактирует естественно.

Первое впечатление является одним из барьеров, который способен содействовать ошибочному восприятию собеседника. Первое впечатление, согласно сущности, не всегда бывает первым, так как на восприятие образа влияет как зрительная, так и слуховая память.

Барьер предвзятой установки выражается в следующем: человек беспричинно начинает отрицательно относиться к собеседнику либо по результату первого впечатления, либо по скрытым личным причинам.

Барьер негативной установки: нам сообщают отрицательную информацию о ком-либо, в процессе чего устанавливается негативная установка по отношению к человеку,с которым мы раннее не взаимодействовали лично. 
Барьер "страха" в общении с человеком: возникают такие моменты, когда нам необходимо вступить в контакт с определенным человеком, но мы боимся это сделать. Так как же вести себя в таких ситуациях? Для начала необходимо спокойно, без лишних эмоций проанализировать, какие факторы нас сдерживают и убедиться в том, что это всё субъективно и имеет второстепенный характер.

Барьер возраста. Люди более старшего поколения зачастую осуждают поведение молодых, а со стороны молодых в такие моменты исходит агрессия.Таким образом,возникают осложнения в отношениях разных поколений.Барьер возраста весьма опасен в различных сферах,как в семейных отношениях,так в социальной сфере(работа).

Схема выхода из ситуации “барьера":

1)оценка сложившейся ситуации барьера, её возможные последствия;

2)обнаружение причин возникновения барьера;

3)определение дальнейших действий для выхода из ситуации.

Для решения проблемы “барьеров” необходимо как можно точно оценить ситуацию, выяснить основные причины и действовать намеченному плану. При этом необходимо учесть основной принцип: принцип взаимопонимания с учетом индивидуальных и психологических особенностей собеседника.

\section{$* * *$}

1. Пастюк, О.В. Психология и педагогика: Учебное пособие / О.В. Пастюк. - М.: НИЦ ИНФРА-М, 2013. - $160 \mathrm{c}$.

2. Пидкасистый, П.И. Психология и педагогика: Учебник для бакалавров / П.И. Пидкасистый. - М.: Юрайт-Издат, 2013. - 724 с. 